\title{
IMPORTANCE OF 6-THIOGUANINE NUCLEOTIDE METABOLITE MONITORING IN INFLAMMATORY BOWEL DISEASE PATIENTS TREATED WITH AZATHIOPRINE
}

\author{
Kristina Pavlovska1, Marija Petrushevska ${ }^{1}$, Kalina Gjorgjievska ${ }^{1}$, Dragica Zendelovska ${ }^{1}$, \\ Jasmina Tonic Ribarska², Igor Kikerkov ${ }^{1}$, Liljana Labachevska Gjatovska ${ }^{3}$, Emilija Atanasovska ${ }^{1}$ \\ ${ }^{1}$ Department of Preclinical and Clinical Pharmacology and Toxicology, Medical faculty, Skopje, Republic of Macedonia \\ ${ }^{2}$ Faculty of Pharmacy, Skopje, R. Macedonia \\ ${ }^{3}$ Institute of Microbiology and Parasitology, Medical faculty, Skopje, Republic of Macedonia
}

Corresponding author: Pavlovska Kristina, 50 Divizija 6, 1000 Skopje, Republic of Macedonia, email: kristina.pavlovska@medf.ukim.edu.mk

\section{ABSTRACT}

The active metabolite of azathioprine, 6-thioguanine nucleotide (6-TGN) is the main component responsible for the immunosuppressive effect in treatment of inflammatory bowel disease (IBD).

The aim of this study was to assess the correlation between the concentration of 6-thioguanine nucleotide and disease activity, azathioprine-related adverse effects and time duration of treatment in patients with inflammatory bowel disease.

Thirty-four patients were included in this study. Type of disease, gender, time duration of therapy and adverse effects were recorded. Metabolite concentration was determined by high performance liquid chromatography.

Twenty-one percent of patients have experienced an adverse effect, with leucocytopenia most commonly occurring $(42.9 \%)$. More adverse effects were registered when patients were treated with azathioprine in a period of less than 3 months in comparison to the group of patients that have been under therapy between 3-12 months and more than 12 months $(p<0.05)$. Most of the patients that presented any adverse effect had high 6-TGN concentration ( $\left.>450 \mathrm{pmol} / 8 \times 10^{8} \mathrm{Er}\right)$. The mean value of 6-TGN metabolite concentration in IBD patients treated with azathioprine was $437.46 \mathrm{pmol} / 8 \times 10^{8} \mathrm{Er} \pm 198.82 \mathrm{pmol} / 8 \times 10^{8}$. The time duration of azathioprine treatment did not have any significant impact on the achieved 6-TGN concentration $(\mathrm{p}>0.05)$.Twenty patients $(58.9 \%)$ had achieved remission after therapy initiation with azathioprine.

More alertness is recommended to clinicians towards patients in the first 3 months of the therapy. Our study demonstrated that higher 6-TGN concentration is associated with azathioprine toxicity.

Keywords: Inflammatory bowel disease, 6-Thioguanine nucleotide, azathioprine

\section{INTRODUCTION}

Immunosuppressive azathioprine (AZA) is widely used in patients with Inflammatory bowel disease (IBD). AZA has proven its efficacy in induction and maintaining remission in Crohn disease and Ulcerative colitis patients. [1,2] Despite the clinical benefit, one-third of the patients treated with AZA are withdrawn either as a result of toxicity, adverse effects (AE's) or a lack of clinical response. [3]

6-Thioguanine nucleotide (6-TGN), the active metabolite is responsible for the immunosuppressive effect of AZA. [4] The monitoring of 6-TGN concentration is suggested to be a successful tool for patient 
detection that do not respond positively to therapy, and/or are dosed suboptimally and in case when predominant methylation exists. In addition, 6-TGN concentration may predict dose-depended toxicity in a way that the side effects might be avoided. [2,5]

Up to now, there are no data available whether 6-TGN concentration measurement could improve the clinical outcome of IBD patients that are on continuous AZA treatment both in terms of efficacy and safety.

The main motive of our research was to investigate the impact of 6-TGN monitoring on further therapeutic decisions in IBD patients. Specifically, we have assessed the correlation between 6-TGN metabolite concentration and disease activity, AZA-related AE's and time duration of AZA treatment in patients with IBD.

\section{MATERIAL AND METHODS}

\section{Data collection}

The study was conducted at the National Center for monitoring of IBD patients at the University Clinic of gastroenterohepatology in Skopje (Macedonia).

All patients with IBD who had been prescribed AZA were identified via a prospective electronic database maintained by IBD clinician specialists. Thirty-four (34) patients were called to come to the clinic at a specified time.

The following variables were recorded: type of IBD (Chron's disease or Ulcerative colitis), gender, AZA duration treatment, determination of 6-TGN concentration with data of AZA dose (mg) when blood sample was collected and possible AE's were registered, as well.

Three groups of patients were identified regarding the time duration of AZA treatment (less than 3 months, between 3-12 months and more than 12 months). Most of the patients (53\%) in this study have used AZA in a period between 3 and 12 months. Disease activity was assessed using Crohn's Disease Activity Index (CDAI) and Ulcerative Colitis Activity Index (UCAI).

\section{Quantification of 6-TGN metabolite}

6-TGN concentration was determined in patients' blood after at least 3 months from the onset of AZA therapy. Full blood was taken from 15 healthy volunteers and 32 patients with IBD who were at least 3 months on treatment with AZA.
Blood samples $(5 \mathrm{~mL})$ were collected in test tubes containing heparin and centrifuged at $4{ }^{\circ} \mathrm{C}$, in order to separate the red blood cells from the whole blood. Then, the red blood cells were settled down to the bottom and the supernatant rich in platelets, as well as the upper layer of cells (leukocytes and platelets) was removed. The RBC concentration in each of the tubes were normalized to $4 \times 109$ erythrocytes. The samples were stored at $-80^{\circ} \mathrm{C}$ until HPLC analysis. To achieve that, $500 \mu \mathrm{L}$ sample was placed in a tube with $5 \mathrm{mg}$ of the internal standard dithiothreitol (DTT), and $50 \mu \mathrm{L}$ perchloric acid was added for deproteinization. Samples were then centrifuged at a $3000 \mathrm{rpm}, 15$ minutes at $4{ }^{\circ} \mathrm{C}$ in order to generate derivatization. Subsequently, the supernatant, the acid extract, was separated and heated for 45 minutes at a temperature of $100{ }^{\circ} \mathrm{C}$, resulting in hydrolysis of the thiopurine nucleotides in free bases. These prepared samples after cooling were injected to the HPLC column, Zorbax Eclipse XDB C18 column, $150 \times 4.5 \mathrm{~mm}, 5 \mu \mathrm{m}$, (Agilent Technologies).

The values obtained for 6-TGN concentrations were categorized into three groups, subtherapeutic $\left(<200 \mathrm{pmol} / 8 \times 10^{8} \mathrm{Er}\right)$, therapeutic $(200-400 \mathrm{pmol}$ $\left./ 8 \times 10^{8} \mathrm{Er}\right)$ and high $\left(>400 \mathrm{pmol} / 8 \times 10^{8} \mathrm{Er}\right)$.

\section{Ethical aspects}

This study was performed in accordance with the principles of the Declaration of Helsinki, Brazil. [6] The study has been approved by the Ethical committee of the Faculty of Medicine in Skopje, University of Ss. Cyril and Methodius.

\section{STATISTICAL ANALYSIS}

Statistical analysis was performed using SPSS for Windows, version 17 (USA). The Fisher-Freeman-Halton exact test was used to determine the association between certain characters in group of patients. The Sperman Rang Order Correlation test was used to determine the correlation between two variables.

In order to test the significance of the difference between certain analyzed parameters, depending on the type and distribution of data, the parametric Student's t-test and ANOVA as well as nonparametric tests for independent samples (Mann Whitney U test) were used. A level of $\mathrm{p} \leq 0.05$ was considered statistically significant. 


\section{RESULTS}

\section{Demographic characteristics}

Thirty-four (34) patients with IBD, of which $22(64.7 \%)$ with Crohn's disease and 12 (35.3\%) with Ulcerative colitis were included in this study. The analysis showed no statistically significant difference between the two clinical types of the disease in relation to the gender of the patients $(\mathrm{p}>$ $0.05)$. The average age of included patients was $40.84 \pm 12.26$ years with a minimum age of 15 and a maximum age of 66 years. A higher average age was seen in patients with Crohn's disease when compared with patients with Ulcerative colitis ( $\mathrm{p}$ $<0.05$, t-test).

\section{Adverse outcomes}

A total of 7 patients $(21 \%)$ have experienced adverse effects. The most commonly occurring AE was leukocytopenia (42.9\%), followed by elevated transaminases $(28.6 \%)$, aphtous ulcers $(14.3 \%)$ and elevated alpha amylase in serum $(14.3 \%)$. More AE's were registered in the group of patients that have used AZA in a period of less than 3 months when compared with the group of patients that have used AZA between 3-12 months and more than 12 months $(\mathrm{p}<0.05)$ (Table 1$)$.

Table 1. Correlation between azathioprine related adverse effects and time duration of azathioprine treatment

\begin{tabular}{|c|c|c|c|c|}
\hline \multirow{2}{*}{$\begin{array}{c}\text { Time duration of AZA } \\
\text { treatment (months) }\end{array}$} & \multicolumn{2}{|c|}{ AZA related AE's } & \multirow{2}{*}{ Total } \\
\cline { 2 - 5 }$<$ & YES & NO & \\
\hline \multirow{2}{*}{$\mathbf{3}$} & Number & 2 & 0 & 2 \\
\cline { 2 - 5 } & $\%$ & $100 \%$ & $0 \%$ & $5,9 \%$ \\
\hline \multirow{2}{*}{$\mathbf{3} \mathbf{1 2}$} & Number & 3 & 15 & 18 \\
\cline { 2 - 5 } & $\%$ & $16,7 \%$ & $83,3 \%$ & $53 \%$ \\
\hline \multirow{2}{*}{$>\mathbf{1 2}$} & Number & 2 & 12 & 14 \\
\cline { 2 - 5 } & $\%$ & $14,3 \%$ & $85,71 \%$ & $41,18 \%$ \\
\hline \multirow{2}{*}{ Total } & Number & 7 & 27 & 34 \\
\cline { 2 - 5 } & $\%$ & $21 \%$ & $79,4 \%$ & $100 \%$ \\
\hline
\end{tabular}

6-TGN concentration

6-TGN concentration was measured only in patients that were treated with AZA in a period of more than 3 months $(\mathrm{N}=32)$. The average 6-TGN concentration in patients with IBD treated with AZA was $437.46 \mathrm{pmol} / 8 \times 10^{8} \mathrm{Er} \pm$ $198.82 \mathrm{pmol} / 8 \times 10^{8} \mathrm{Er}\left(\mathrm{min} .64 .8 \mathrm{pmol} / 8 \times 10^{8} \mathrm{Er}\right.$ and max. $\left.905.5 \mathrm{pmol} / 8 \times 10^{8} \mathrm{Er}\right)$. Fifty percent of the patients $(50 \%)$ had 6-TGN values above 399.8 $\mathrm{pmol} / 8 \times 10^{8} \mathrm{Er}$.
Patients treated with AZA between 3 to 12 months had average 6-TGN concentration of $460.06 \mathrm{pmol} / 8 \times 10^{8} \mathrm{Er} \pm 206.61 \mathrm{pmol} / 8 \times 10^{8} \mathrm{Er}$ (min. $64.8 \mathrm{pmol} / 8 \times 10^{8} \mathrm{Er}$, max. $905.5 \mathrm{pmol} / 8 \times 10^{8}$ Er). Fifty $(50 \%)$ percent of these patients had 6-TGN value above $427.9 \mathrm{pmol} / 8 \times 10^{8} \mathrm{Er}$.

The range for 6-TGN in the group of patients that were under AZA treatment more than 12 months was between $205.1 \mathrm{pmol} / 8 \times 10^{8} \mathrm{Er}$ and $746.4 \mathrm{pmol} / 8 \times 10^{8} \mathrm{Er}$, average concentration of $404.42 \mathrm{pmol} / 8 \times 10^{8} \mathrm{Er} \pm 189.99 \mathrm{pmol} / 8 \times 10^{8} \mathrm{Er}$. Fifty $(50 \%)$ percent of these patients had 6-TGN value above $361.5 \mathrm{pmol} / 8 \times 10^{8} \mathrm{Er}$.

The time duration of AZA treatment did not affect the concentration of achieved 6-TGN metabolite $(\mathrm{p}>0,05)$.

\section{6-TGN concentration and time duration of AZA treatment}

An additional analysis of 6-TGN metabolite concentration was performed, where patients were divided in 3 groups i.e., group 1 with subtherapeutic values of 6 -TGN $\left(<200 \mathrm{pmol} / 8 \times 10^{8} \mathrm{Er}\right)$; group 2 with therapeutic values of 6-TGN (200$\left.400 \mathrm{pmol} / 8 \times 10^{8} \mathrm{Er}\right)$ and group 3 with high values of 6-TGN ( $\left.>400 \mathrm{pmol} / 8 \times 10^{8} \mathrm{Er}\right)$.

Most of the patients (57.89\%) that have used AZA in a period between 3-12 months belonged to group 3 (high 6-TGN concentration), 31.58\% belonged to group 2 (therapeutic 6-TGN concentration) and $10.53 \%$ belonged to the subtherapeutic group $1(\mathrm{p}>0.05)$.

Our analyzes demonstrated that in the group of patients treated with AZA in a period of more than 12 months, $61.54 \%$ were in the therapeutic range of 6-TGN and $38.46 \%$ had high concentration values of 6-TGN. No patient was found to be in the subtherapeutic group (group 1) ( $>00.05)$.

\section{6-TGN concentration and adverse effects}

Patients who were treated with AZA and where AE's were registered had higher mean value of 6-TGN when compared with those patients where no AE's were noticed (487.54 pmol $/ 8 \times 10^{8}$ $\mathrm{Er} \pm 185.57 \mathrm{pmol} / 8 \times 10^{8} \mathrm{Er}$ vs. $429.11 \mathrm{pmol} / 8 \times 10^{8}$ $\mathrm{Er} \pm 203.39 \mathrm{pmol} / 8 \times 10^{8} \mathrm{Er}$ (t-test, $\mathrm{p}>0.05$ ).

Fifty $(50 \%)$ percent of patients with AE's had average value of 6-TGN concentration above $562.8 \mathrm{pmol} / 8 \times 10^{8} \mathrm{Er}$, compared with the group of patients who did not present AE's, where average 
value for 6-TGN concentration in $50 \%$ of them was $399.5 \mathrm{pmol} / 8 \times 10^{8} \mathrm{Er}$ (Figure 1).

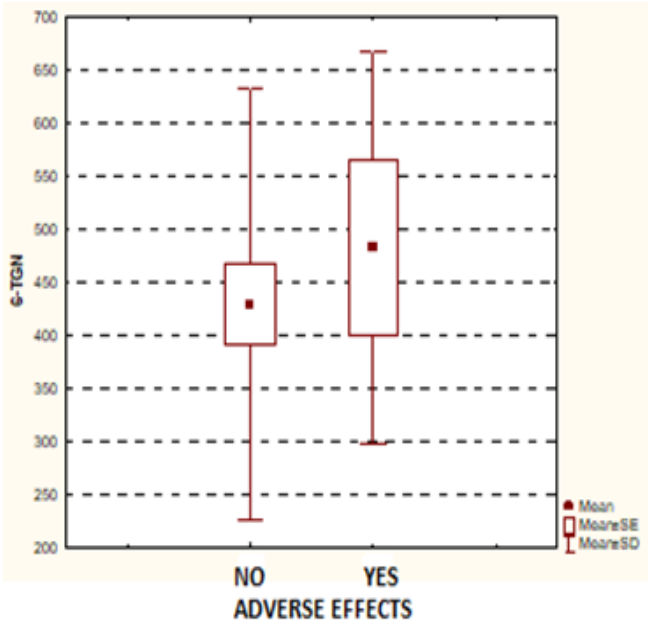

Figure 1. 6-Thioguanine nucleotide concentration and adverse effects

Most of the patients that presented any AE had high 6-TGN concentration (group 3) where 6-TGN concentration was above $450 \mathrm{pmol} / 8 \times 10^{8} \mathrm{Er}$. None of the patient who had subtherapeutic 6-TGN concentration (group 1) had presented AE (Table 2).

Table 2. Correlation between 6-Thioguanine nucleotide concentration and adverse effects

\begin{tabular}{|c|c|c|c|c|}
\hline \multirow{2}{*}{\multicolumn{2}{|c|}{ 6-TGN concentration }} & \multicolumn{2}{|c|}{$\mathbf{A E}$} & \multirow{3}{*}{$\begin{array}{c}\text { Total } \\
2\end{array}$} \\
\hline & & \multirow{2}{*}{$\begin{array}{c}\text { YES } \\
0\end{array}$} & \multirow{2}{*}{$\begin{array}{c}\text { NO } \\
2\end{array}$} & \\
\hline Group 1 & Number & & & \\
\hline $\begin{array}{l}<200 \mathrm{pmol} / 8 \times 10^{8} \\
\mathrm{Er}\end{array}$ & $\%$ & $0,00 \%$ & $100 \%$ & \\
\hline \multirow{2}{*}{$\begin{array}{c}\text { Group 2 } \\
\text { Therapeutic } \\
200-400 \mathrm{pmol} / \\
8 \times 10^{8} \mathrm{Er}\end{array}$} & Number & 2 & 12 & 14 \\
\hline & $\%$ & $14,29 \%$ & $85,71 \%$ & \\
\hline \multirow{2}{*}{$\begin{array}{c}\text { Group 3 } \\
\text { high } \\
>400 \mathrm{pmol} / 8 \times 10^{8} \\
\mathrm{Er}\end{array}$} & Number & 3 & 13 & 16 \\
\hline & $\%$ & $18,75 \%$ & $81,25 \%$ & \\
\hline \multirow{2}{*}{ Total } & Number & 5 & 27 & 32 \\
\hline & $\%$ & $15,63 \%$ & $84,38 \%$ & $100 \%$ \\
\hline
\end{tabular}

\section{6-TGN concentration and disease activity}

From 34 patients treated with AZA in this study, remission was registered in $20(58.9 \%)$ of them. The rest 14 patients $(41.2 \%)$ remained in acute phase of the disease. No statistical significance was found between the two types of the disease (Crohn's disease vs. Ulcerative colitis) regarding the percent of patients that have achieved remission (13 patients $(59.1 \%)$ vs. 7 patients $(58.3 \%))$.
As 6-TGN metabolite concentration increased, the probability of remission rose $(\mathrm{p}>0.05$; $\mathrm{R}=0.0819$ ) (Figure 2a).
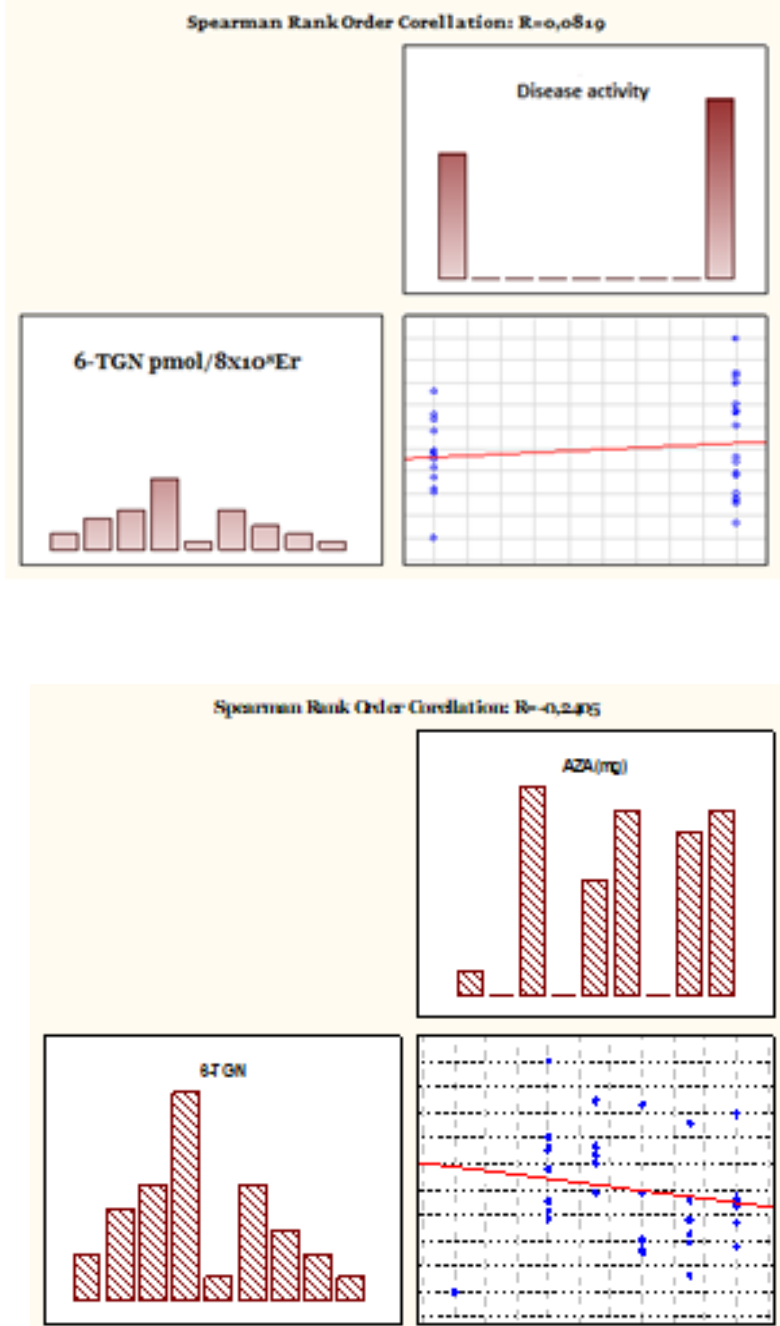

Figure 2. a) Non-parametric correlation between 6-Thioguanine nucleotide concentration and disease activity; b) Non-parametric correlation between azathioprine doze and 6-Thioguanine nucleotide concentration

\section{6-TGN concentration, AZA dose ( $m g$ ) and AE's}

Average AZA dose at the moment of blood sample collection for determination of 6-TGN concentration was $164.7 \pm 27.3 \mathrm{mg}$ (min. $100 \mathrm{mg}$; max. $200 \mathrm{mg}$ ). Fifty (50) percent of the patients had received AZA dose above $200 \mathrm{mg}$. The performed analysis for the association between AZA dose and 6-TGN concentration showed the existence of a linear indirect correlation $(\mathrm{R}=-0.2405)$. As the dose of AZA was increasing, the concentration of 6-TGN metabolite was reduced (Figure 2b). Higher dose of AZA was found to be administered in patients who did not present any AE in comparison with the group of patients where AE's were 
registered $(168 \pm 25.4 \mathrm{mg}$, $\min .100 \mathrm{mg}$, max.200 $\mathrm{mg}$ vs. $146.6 \pm 30.4 \mathrm{mg}$, min. $125 \mathrm{mg}$, max.200 $\mathrm{mg})$, (t-test, $\mathrm{p}=0.0489$ ).

\section{DISCUSSION}

In the clinical practice, $25 \%$ of patients may not respond to AZA or 6-MP, 30\% may experience relapse during treatment, while $15-30 \%$ of patients may develop adverse effects (7).

Herein we presented that monitoring of AZA metabolites can predict the clinical response in patients with IBD, and thus individualize therapeutic treatment.

Twenty-one (21) percent of patients who were on AZA therapy at the time of this study $(\mathrm{N}=34)$, experienced adverse effects. Similar results were reported by Saibeni et al., 27.4\% (8). The literature data show, bone marrow suppression in $2-5 \%$ of cases in IBD patients treated with thiopurine and leucocytopenia in $2-4 \%$ of the patients treated with AZA or 6-MP (9). Pancreatitis occurs in about $4 \%$ of patients treated with thiopurine, usually in the first weeks of starting the treatment (10).

Data from our study support these findings where leukocytopenia was the most common seen $\mathrm{AE}$ in our patients (42.9\%). Our study also demonstrated significant differences in the duration of AZA therapy (less than 3 months, between 3-12 months and > 12 months) and the number of reported adverse effects $(100 \%$ vs $16.7 \%$ versus $14.3 \%), p<0.05$. Intolerance to AZA appears at lower initial doses, after which the drug is either excluded, or if possible, the dose is decreased (11). Our results showed a difference in the average value of AZA doses, in addition to a higher dose of the drug in the group of patients not having adverse effects compared to the group of patients who reported adverse effects $(168 \mathrm{mg} \pm 25.4 \mathrm{mg}$ v.s $146.6 \mathrm{mg} \pm 30.4 \mathrm{mg})$ $(\mathrm{p}<0.05)$.

Azathioprine has a slow effect, with a half time to achieve a therapeutic response of 3 months. The long time required to achieve the therapeutic response is thought to correlate with the accumulation of 6-TGN and the attainment of a steady-state condition. In adults with $\mathrm{CD}$, the half time to achieve steady-state of the 6-TGN metabolite is 5 weeks (12).
The highest percentage of adverse effects was registered in patients with high concentration of 6-TGN (18.75\%), followed by the group of therapeutic concentration (14.29\%). High concentration of 6-TGN is associated with an increased occurrence of leucocytopenia, lymphopenia, and the use of mesalazine (13). In a study by Lee et al. (13), the occurrence of leucocytopenia $(p=0.025)$ and lymphopenia $(p=0.045)$ are associated with high concentrations of 6-TGN.

No statistical significance was found between the dose of AZA and the concentration of 6 -TGN ( $>>0.05)$. Literature data are contradictory. Zhang et al., (14) and Gearry et al., (15) confirm our results in their studies, but in the study by Lee et al. (13) a positive correlation was found between the dose of AZA and concentration of 6 -TGN $(p<0.0001)$. Some factors may influence the acceleration of 6-TGN pharmacokinetics. Changes in azathioprine absorption or interactions with other drugs such as mesalazine, balsalazide and sulphasalazine are associated with increasing the 6-TGN concentration in red blood cells $(16,17)$. Also, the lack of method standardization for concentration determination of 6-TGN may be one of the reasons for these contradictory results.

Fraser et al. (18) demonstrated the safety and efficacy of AZA in the treatment of IBD. The long-term outcome of treatment with thiopurines in IBD patients in real life has so far been studied in several observational studies. The percentage of patients who achieved remission after thiopurine use was recorded in the studies of Saibeni et al., (46.6\%) and Fraser et al., (45\% CD, 58\% UC) $(8,18)$. These data are in line with our results, which showed that following treatment with AZA, $58.9 \%$ of patients achieved remission.

\section{CONCLUSION}

The majority of the AE's were reported at the beginning of the treatment with AZA, hence more alertness is recommended to clinicians towards these patients in the first 3 months of initiation of the therapy. Our study suggested that higher 6-TGN concentration is associated with azathioprine toxicity. Studies, with larger sample of patients are needed to investigate the exact mechanism of 6-TGN in IBD patients treated with AZA. 


\section{Conflict of interest statement}

I have nothing to disclose.

\section{Acknowledgements}

Authors would like to thank Maja Slaninka Miceska, Petranka Mishevska and Nikola Labachevski for scientific proposals and critical review of the manuscript.

\section{REFERENCES}

1. Sandborn W, Sutherland L, Pearson D, et al. Azathioprine or 6-mercaptopurine for induction of remission of Crohn's disease. Cohrane Database System Rev.2, CDOOO545.

2. Smith M, Blacker P, Patel C, et al. The impact of introducing thioguanine nucleotide monitoring into an inflammatory bowel disease clinic. Int $\mathbf{J}$ Clin Pract. 2013; 67(2): 161-9.

3. Connell WR, Kamm MA, Ritchie JK, et al. Bone marrow toxicity caused by azathioprine in inflammatory bowel disease: 27 years of experience. Gut 1993; 34: 1081-5.

4. D'Halluin PN, Tribut O, Branger B, et al. RBC 6-TGN and hematological parameters in patients with Crohn's disease treated by azathioprine. Gastroenterol Clin Biol. 2005; 29: 1264-9.

5. Cuffari C, Hunt S, Bayless T. Utilisation of erythrocyte 6-thioguanine metabolite levels to optimize azathioprine therapy in patients with inflammatory bowel disease. Gut. 2011; 48: 642-6.

6. Declaration of Helsinki, Ethical Principles for Medical Research Involving Human Subject as amended. Helsinki. 2013.

7. Al Hadithy AF, de Boer NK, Derijks LJ, et al. Thiopurines in inflammatory bowel disease: pharmacogenetics, therapeutic drug monitoring and clinical recommendations. Dig Liver Dis. 2005; 37: 282-97.

8. Saibeni S, Virgilio T, D'Inca R, et al. The use of thiopurines for the treatment of inflammatory bowel diseases in clinical practice. Dig Liver Dis. 2008; 40(10): 814-20.
9. McLean L, Cross R. Adverse events in IBD: to stop or continue immune suppressant and biologic treatment. Expert Rev Gastroenterol Hepatol. 2014; 8(3): 223-40.

10. Chaparro M, Ordas I, Cabre E, et al. Safety of thiopurine therapy in inflammatory bowel disease:long-term follow up study of 3931 patients. Inflamm Bowel Dis.2013; 19(7): 1404-10.

11. Ansari A, Hassan C, Duley J, et al. Thiopurine methyltransferase activity and the use of azathioprine in inflammatory bowel disease. Aliment Pharmacol Ther. 2002; 16: 1743-50.

12. Hindorf $U$, Lindqvist $M$, Peterson $C$, et al. Pharmacogenetics during standardised iniciation of thiopurine treatment in inflammatory bowel disease. Gut. 2006; 55: 1423-31.

13. Lee MN, Kang B, Choi SY, et al. Relationship between azathioprine dosage, 6-thioguanine nucleotide levels, and therapeutic response in pediatric patients with IBD treated with azathioprine. Inflamm Bowel Dis. 2015; 21(5): 1054-62.

14. Zhang B, Xu X, Zeng X, et al. Correlation of Thiopurine Methyltransferase Activity and 6Thioguanine Nucleotide Concentration in Han Chinese Patients treated with Azathioprine 25 to 100mg: A 1-Year Single-Center, Prospective study. Cur Ther Research. 2006; 67(4): 270-82.

15. Gearry RB, Barclay ML, Roberts RL, et al. Thiopurine methyltransferase and 6-thioguanine nucleotide measurement: early experience of use in clinical practice. Inter Med J. 2005; 35(10): 580-5.

16. Cohen R. Forecast for using metabolite measurements in the dosing of azathioprine or 6-mercaptopurine for IBD patients: "Partly cloudy". Gastroenterol 2002; 122: 2082-84.

17. Lowry PW, Franklin CL, Weaver AL, et al. Leukopenia resulting from a drug interaction between azathioprine or 6-mercaptopurine and mesalamine, sulphasalazine, or balsalazide. Gut. 2001; 49: 656-64.

18. Fraser AG, Orchard TR, Jewell DP. The efficacy of azathioprine for the treatment of inflammatory bowel disease; a 30 year review. Gut. 2002; 50: 485-9. 


\title{
Резиме
}

\section{ВАЖНОСТА НА МОНИТОРИРАњЕ НА 6-ТИОГВАНИН НУКЛЕОТИД МЕТАБОЛИТ КАЈ ПАЦИЕНТИ СО ВОСПАЛИТЕЛНИ ЦРЕВНИ ЗАБОЛУВАЊА ТРЕТИРАНИ СО АЗАТИОПРИН}

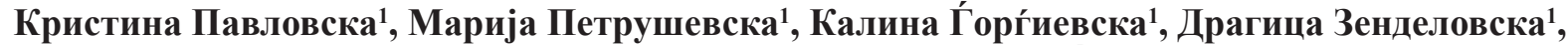 \\ Јасмина Тониќ Рибарска ${ }^{2}$, Игор Кикерков ${ }^{1}$, Лилјана Лабачевска Ѓ Гтовска ${ }^{3}$, Емилија Атанасовска ${ }^{1}$ \\ ${ }^{1}$ Институт за претклиничка и клиничка фармакологија со токсикологија, Медицински факултет, \\ Скопје, Република Македонија \\ 2 Фармацевтски факултет, Скопје, Република Македонија \\ ${ }^{3}$ Институт за микробиологија и паразитологија, Медицински факултет, Скопје, Република Македонија
}

Активниот метаболит на азатиоприн - 6-тиогванин нуклеотид (6-TGN) е главната компонента што е одговорна за имуносупресивниот ефект на лекот во третманот на пациентите со воспалителни цревни заболувања (ВЦЗ).

Целта на оваа студија беше да се процени поврзаноста меѓу концентрацијата на 6-тиогванин нуклеотид и активноста на болеста, несаканите реакции поврзани со употребата на азатиоприн и времетраењето на третманот кај пациентите со ВЦЗ.

Во оваа студија беа вклучени триесет и четири пациенти. Регистрирани беа: клиничкиот тип на болеста, полот, времетраењето на терапијата со азатиоприн и несаканите реакции. Концентрацијата на 6-тиогванин нуклеотид беше определена со употреба на методата HPLC (high performance liquid chromatography), која за оваа цел првпат беше поставена во Република Македонија.

Кај дваесет и еден процент од пациентите беше регистрирана несакана реакција. Најчеста несакана реакција беше леукоцитопенија (42,9 \%). Поголем процент на несакани реакции беа регистрирани кај пациентите што беа третирани со азатиоприн во период пократок од три месеци, во споредба со групата пациенти што беше подложена на терапија во период од 3 до 12 месеци и повеќе од 12 месеци $(\mathrm{p}<0,05)$. Најголемиот процент од пациентите кај кои беше регистрирана несакана реакција имаа висока 6-TGN концентрација (> 450 pmol / 8x108 Er). Средната вредност на концентрацијата на 6-TGN метаболитот кај пациентите со ВЦЗ третирани со азатиоприн беше 437,46 $\mathrm{pmol} / 8 \mathrm{x} 108 \mathrm{Er} \pm 198,82 \mathrm{pmol} /$ 8x108. Времетраењето на третманот со азатиоприн не влијаеше на постигнатата концентрација на 6-TGN (p > 0,05). Дваесет пациенти $(58,9 \%$ ) постигнаа ремисија по започнување на терапијата со азатиоприн.

На медицинскиот персонал што ординира терапија со азатиоприн му се препорачува особено внимание да посвети на пациентите во првите три месеци од започнувањето на терапијата. Нашата студија покажа дека високата концентрација на 6-TGN метаболит се поврзува со азатиопринска токсичност.

Клучни зборови: воспалителни цревни заболувања, 6-тиогванин нуклеотид, азатиоприн 